\title{
The monoblock concept in endodontics
}

\author{
Manjula Kittur ${ }^{1, *}$, Sheetal Ghivari ${ }^{2}$, Madhu Pujar ${ }^{3}$, Deepa Astekar ${ }^{4}$, Neha Arora ${ }^{5}$ \\ ${ }^{1,4,5}$ Post Graduate, ${ }^{2}$ Reader, ${ }^{3}$ Professor HOD, ${ }^{1-5}$ Dept. of Conservative Dentistry and Endodontics, Maratha Mandal Dental \\ College, Belagavi, Karnataka, India
}

*Corresponding Author:

Email: drmanjushreek@gmail.com

\begin{abstract}
The ultimate challenge for successful endodontic therapy is to establish a homogenous unit of the root canals which requires a hermetic seal. Adhesion of root canal sealers to dentin is important to seal the root canal system thoroughly and to prevent microleakage. Bonding of root filling materials to the radicular dentin is known as 'monoblocks' which has become more popular after introduction of bonding concept in the root canal system. The aim of this review highlights on newer materials and different concepts in rehabilitation of root canal space. Thus the potential of these monoblocks is discussed with the possibility of their application in endodontics in future.
\end{abstract}

Keywords: Monoblocks, MTA, Fibre posts, Bonding to root canal.

\section{Introduction}

Success of root canal therapy depends upon thorough cleaning, shaping and three dimensional obturation. In order to obtain a hermetic seal, the core filling materials and the sealers used to seal the root canal must create different interfaces forming a monoblock.

The term Monobloc was introduced by Dr. Pierre Robin in 1902 in the field of Orthodontics which refers to a "Single unit" where as in endodontics the word monoblock represents a compactly filled space with the bonding substrate and core material that constitutes different material interfaces. ${ }^{1}$ Based upon these interfaces monoblocks are classified in to primary monoblock, secondary monoblock and tertiary monoblock. ${ }^{2}$ To satisfy the standards the monoblock should possess adequate bond strength as well as modulus of elasticity comparable to that of dentin. ${ }^{3}$ The bonding ability of these monoblocks in the root canal has some disputes which would not assure the perfect seal and also associated with variations in the modulus of elasticity of resin based obturating materials compared to that of dentin. Therefore the future research should focus on introducing the newer materials which possess modulus of elasticity similar to dentin and the good sealing ability which leads to success of monoblocks.

\section{Primary Monoblock}

The single circumferential interface formed between the root canal wall and the obturating material is called 'Primary monoblock' Egs. Mineral Trioxide Aggregate (MTA), hydron, polyethylene fibre post-core systems, Biogutta. The materials under primary monoblocks can be manipulated easily, non-irritating with acceptable adaptability, and ability to calcify even if it gets forced out of the canal accidentally. MTA helped in fortifying the teeth by forming interfacial apatite deposits resulting in good seal. ${ }^{4}$ The modulus of elasticity of hydron is less than that of dentin which is not acceptable in creating the primary monoblock for fortifying the roots. ${ }^{4}$ The interfacial stresses can be altered accordingly at the interface between resin and dentin when Polyethylene fibre post-core systems having comparable modulus of elasticity to that of dentine are used. Biogutta which contains polyisoprene matrix with bioactive glass of $45 \mathrm{~s} 5$ type which exhibits self-adhesive property with immediate sealability. ${ }^{5}$

\section{Secondary Monoblock}

The system in which two circumferential interfaces are formed one between the cement - core material and other between cement- dentin are categorised as 'secondary monoblocks. Ex:resilon, Fibre re-inforced posts. A polycaprolactone based bioactive containing glass such as resilon shows good bonding ability with the sealer through the process of polymerization. ${ }^{6}$ The epoxy resin based carbon fibre reinforced posts bond to the root canal wall through oxidation process with comparable modulus of elasticity to that of dentin, could achieve a monoblock between the tooth-postcore. ${ }^{1}$

\section{Tertiary Monoblock}

The system in which three interfaces are formed circumferentially, between the dentin - cement, between cement - bonding substrate and lastly between bonding substrate - abutment material. Egs. fibre posts+ external silane, endorez. Endorez are the resin coated gutta-percha cones which are used with the radiopaque methacrylate sealer. ${ }^{7}$

\section{Problems Associated in Bonding}

Polymerisation of resin materials will lead to shrinkage, resulting in separation at the areas of weakest bond through which micro-organisms can ingress in to the root canals. ${ }^{8}$ Configuration factor (Cfactor) is the ratio of bonded to unbonded resin surface area which is supposed to be less than 3 for effective bonding. ${ }^{10}$ However due to complex root canal configuration the ratio was found to be more than 1000 causing debonding at the dentin-sealer interface. ${ }^{11}$ Time 
factor is also considered to be one of the problem associated with bond strength, as it gets deteriorated with time. ${ }^{8,12}$ The apical one-third of the radicular dentine contains less number of dentinal tubules than the coronal dentine accounting for less resin tag formation during the adhesion procedure. ${ }^{13}$ It has been reported that the hybrid layer favours the bond strength rather than resin tag formation. ${ }^{14}$ As radicular dentine contains more intertubular dentine it results in more hybrid layer formation which is favourable for bonding. ${ }^{15}$

\section{Sealability of Monoblock Interfaces}

Achieving a hermetic seal throughout the root canal system either chemically or micromechanically is necessary for the successful outcome. Probable causes of microleakage could be due to poor adhesion wettability, polymerization shrinkage, thermal stresses, occlusal loading and water sorption. ${ }^{16}$ In order to overcome these instances bonded obturating materials and methacrylate resin based root canal sealers were developed for improving the sealing ability of root filling materials such as first generation MBRS; Hydron, second generation; ENDOREZ, third generation; RESILON/EPIPHANY the fourth generation; METASEAL.

\section{Effect of Medicaments Irrigants and Smear Layer with the Monoblock}

Sodium hypochlorite is a very important irrigant used in root canal disinfection which possesses a strong antibacterial activity and results in the formation of an oxygen rich layer on the surfaces of dentin causing weak bond strength with the resin based sealers. According to various studies smear layer elimination before obturation has been a controversial aspect. However the current recommendation is to remove the smear layer before obturation by alternative use of NaOCL, EDTA, MTAD and citric $\operatorname{acid}^{19}$ with ultrasonic instruments ${ }^{18}$ for better clinical performance.

\section{Biocompatibility}

An ideal obturation material creating a monoblock should be nonmutagenic, noncarcinogenic ${ }^{20}$, nonirritating $^{21}$ and biocompatible to periradicular tissues. $^{22}$ An in vivo study on guinea pigs was performed to check the biocompatibility of primary monoblock (MTA) ${ }^{23}$, secondary monoblock (resilon) ${ }^{24}$ and tertiary monoblock ${ }^{23}$ (endorez). A cytotoxicity evaluation revealed better biocompatibility and more viable cell count and moderate to severe levels of inflammation were seen with the three monoblocks tested.

\section{Clinical Significance}

Till date only one study has compared the clinical outcome of endodontic therapy using guttapercha and resilon and reported no significant difference. However pawińska et al. carried out a case-series study and investigated the outcome of endodontic treatment using resilon, and proved that resilon showed a successful treatment outcome. ${ }^{25}$

\section{Conclusion}

The Modulus of elasticity and sealing ability are the two controversies associated with the monoblocks which do not contribute for the root fortification. ${ }^{26,27}$ Despite several draw backs in the theory it is said that the future of endodontics should focus on developing newer materials to attain a leak free hermetic sealing interface between the root canal wall and the obturating materials fulfilling the criterias required for the concept of monoblock.

\section{References}

1. Dallari A, Rovatti L. Six years of in vitro in vivo experience with Composipost. Compend Contin Educ Dent Suppl. 1996;(20):57-63.

2. Tay FR, Pashley DH. Monoblocks in root canals: A hypothetical or a tangible goal. J Endod. 2007;33(4):39198.

3. Tay FR and Pashley DH. Monoblocks in root canals: a hypothetical or a tangible goal. J Endod. 2007; 33:39198.

4. Andreasen JO, Munksgaard EC, Bakland LK. Comparison of fracture resistance in root canals of immature sheep teeth after filling with calcium.

5. Marending M, Bubenhofer SB, Sener B, De-Deus G. Primary assessment of a self-adhesive gutta-percha material. Int Endod J. 2013;46(4):317-22.

6. Bodrumlu E, Tunga U. Coronal sealing ability of a new root canal filling material. J Can Dent Assoc. 2007;73(7):623.

7. Tay FR, Loushine RJ, Monticelli F, Weller RN, Breschi L, Ferrari M, et al. Effectiveness of resin-coated guttapercha cones and a dual-cured, hydrophilic methacrylate resin-based sealer in obturating root canals. J Endod. 2005;31(9):659-64.

8. De Munck J, Van Landuyt K, Peumans M, Poitevin A, Lambrechts P, Braem M and Van Meerbeek B. A critical review of the durability of adhesion to tooth tissue: Methods and results. J Dent Research. 2005;84:118-32.

9. Carvalho RM, Pereira JC, Yoshiyama M and Pashley $\mathrm{DH}$. A review of polymerization contraction: the influence of stress development versus stress relief. Oper Dent. 1996;21:17-24

10. Yoshikawa T, Sano H, Burrow MF, Tagami J and Pashley DH. Effects of dentin depth and cavity configuration on bond strength. J Dent Research. 1999;78:898-905.

11. Tay FR, Loushine RJ, Lambrechts P, Weller RN and Pashley DH. Geometric factors affecting dentin bonding in root canals: a theoretical modeling approach. $J$ Endod. 2005;31:584-89.

12. Hashimoto M, Ohno H, Kaga M, Endo K, Sano H and Oguchi $\mathrm{H}$. In vivo degradation of resin-dentin bonds in humans over 1 to 3 years. $J$ Dent Research. 2000;79:1385-91.

13. Mjör IA, Smith MR, Ferrari M and Mannocci F. The structure of dentine in the apical region of human teeth. Int Endod J. 2001;34:346-53.

14. Tagami J, Tao L and Pashley DH. Correlation among dentin depth, permeability, and bond strength of adhesive resins. Dental Materials. 1990;6:45-50. 
15. Ferrari M, Mannocci F, Vichi A, Cagidiaco MC and Mjör IA. Bonding to root canal: structural characteristics of the substrate. Ame J dent. 2000;13:255-60.

16. Kanca J III. Wet bonding: Effect of drying time and distance. Am J Dent. 1996;9:273-76.

17. Estrela C, Estrela CRA, Barbin EL, et al. Mechanism of action of sodium hypochlorite.Braz Dent J. 2002;13:11317.

18. Violich DR and Chandler NP. The smear layer in endodontics-a review. Int Endod J. 2009;43:2-15.

19. Shashidhar C, Shivanna V, Shivamurthy GB and Shashidhar J. The comparison of microbial leakage in roots filled with resilon and gutta-percha: An in vitro study. J Conservative Dent. 2011;14:21-7

20. Grossman LI. Endodontic practice.10th ed. Philadelphia Lea \&Febige. 1982;297.

21. Torabinejad M, Kettering JD, Bakland LK. Evaluation of systemic immunological reactions to $\mathrm{AH}-26$ root canal sealer.J Endod. 1979;5:196-200.

22. Donadio M, Jiang J, Safavi KE, Zhu Q. Cytotoxicity evaluation of Active GP and Resilon cones in vitro. Oral Surg Oral Med Oral Pathol Oral Radiol Endod. 2008;106:76-9.
23. De Campos-Pinto MM, de Oliveira DA, Versiani MA, Silva-Sousa YT, de Sousa-Neto MD, da Cruz Perez DE. Assessment of the biocompatibility of Epiphany root canal sealer in rat subcutaneous tissues. Oral Surg Oral Med Oral Pathol Oral Radiol Endod. 2008;105:77-81.

24. Key JE, Rahemtulla FG, Eleazer PD. Cytotoxicity of a new root canal filling material on human gingival fibroblasts. J Endod. 2006;32:756-8.

25. Conner DA, Caplan DJ, Teixeira FB and Trope M. Clinical outcome of teeth treated endodontically with a non-standardized protocol and root filled with resilon. $J$ Endod. 2007;33:1290-92.

26. Goracci C, Raffaelli O, Monticelli F, Balleri B, Bertelli E, Ferrari M. The adhesion between prefabricated FRC posts and composite resin cores: microtensile bond strength with and without post-salinization Dent Mater. 2005;21(5):437-44.

27. Wrbas KT, Schirrmeister JF, Altenburger MJ, Agrafioti A, Hellwig E. Bond strength between fibre posts and composite resin cores: effect of post surface silanization. Int Endod J. 2007;40(7):538-43. 